\title{
Accounting and control procedures in risk assessment of information environment distortion
}

\author{
Viktoriya $V$. Alekseeva and Irina $V$. Milgunova* \\ Management and Audit Department, Southwest State University, Kursk, Russia
}

\begin{abstract}
Accounting and control is the foundation of prosperous business. It is impossible to create an effective internal control system without taking into account the organizational and methodological aspects of the accounting process. Therefore, there appears a need for an integrated assessment of accounting and control procedures as a single unified system. The application and introduction of state-of-the art digital technologies is of great importance during the development of high-technology business. In this regard, there is a need to find a system or technology that could make it possible to generalize accounting and control procedures to reduce the risk of the information environment distortion. One of such technologies that implements the formation of a continuous sequential chain of blocks is the blockchain technology. The present article specifies the structure and content of accounting and control procedures blocks using the blockchain technology. The selected blocks include accounting and control procedures based on the sequence of the accounting process. As a rule, control procedures applied by an economic entity do not cover all the risks of accounting information distortion. For that reason, one needs to assess them in order to determine the risks and minimize them. To assess the risks of the information environment distortion, a methodology based on the evaluation of their coverage completeness by accounting and control procedures has been developed. Through a well-rounded assessment of the information environment distortion risk, the proposed methodology will allow one to form accounting information systematically as well as in a quality manner and manage control procedures in order to make effective management decisions.
\end{abstract}

Being one of the functions of the management system, control covers all aspects of both daily life and professional activities in any industry. The necessity to implement control procedures is due to the fact that timely identification of violations and unscrupulous actions in an organization contributes to improving efficiency in making managerial decisions [1].

It is impossible to create an effective internal control system without taking into account the organizational and methodological aspects of the accounting process, since they are

\footnotetext{
*Corresponding author: milg_irina@mail.ru
} 
diverse in terms of the degree of automation, industry-specific features of economic entities' activities, the form of accounting information processing used, and other factors.

Thus, the significance of the accounting process can be explained by the fact that an organization, firstly, cannot manage the transactions performed without accounting, and secondly, the organization and methodology of the accounting process affects the indicators of financial (accounting) statements. Therefore, a need arises for an integrated assessment of accounting and control procedures as a single unified system.

Russian researchers V. I. Podolsky [2], N. N. Khakhonova, I. N. Bogataya, R. P. Bulyga [3], M. V. Melnik [3], L. V. Sotnikova, A.D. Sheremet [4], E. M. Merzlikina and others made a significant contribution to the development and scientific justification of the methodology to assess accounting and control procedures and the risks of material misstatement of accounting financial statements.

The problems of assessing the accounting, internal control, accounting and control procedures are generally considered in the works of foreign scientists: R. Adams [5], A. L. Ahrens, J. K. Lobbeck [6], E. A. Kobets, D. K. Robertson [7], E. Kaplan and others.

However, the methodology for assessing the accounting and control procedures, with regard to the development and introduction of digital technologies, is not fully studied. In order to implement the Strategy for the Development of the Information Society in the Russian Federation for 2017-2030 [8], the development of high-tech business should be accompanied by the use and introduction of modern digital technologies. The environment is one of the levels of the digital economy development. It creates conditions for developing platforms and technologies for the effective functioning of market entities and economic sectors

There is a problem of creating an effective system for collecting, processing, storing and providing data that provides business with up-to-date and reliable information about spatial objects.

Its solution is possible as a result of creating an information shell or technology to improve the quality of accounting and control procedures and methods of their assessment.

In this regard, it is necessary to find a system or technology that will allow generalizing accounting and control procedures to reduce the risks of indicators distortion of financial and economic activity of a business unit. Systematization is possible with the definition of elements (blocks) that characterize each stage of accumulation and control of accounting information. The blockchain is one of those technologies that implements the formation of a continuous sequential chain of blocks.

A block is an information cell that contains information about previous and new operations in the system. The entire chain of such blocks is an information database.

We believe that the stages of treatment and internal control of economic events in all accounting processes (accounting, tax, management) - this is a consistent chain of accounting and control information formation to assess the risks of its distortion.

In relation to the accounting process, including the preparation of accounting (financial) statements, risk assessment has been designed to identify risks that may affect the reliability of accounting (financial) statements. In the course of such an assessment, the probability of accounting and reporting data misstatement is considered based on the following assumptions: occurrence and existence, completeness, rights and obligations, assessment and distribution, presentation and disclosure.

In our opinion, accounting and control procedures can be built in the form of sequential blocks. The proposed structure of accounting and control procedures blocks for use in blockchain technology is shown in Figure 1. 


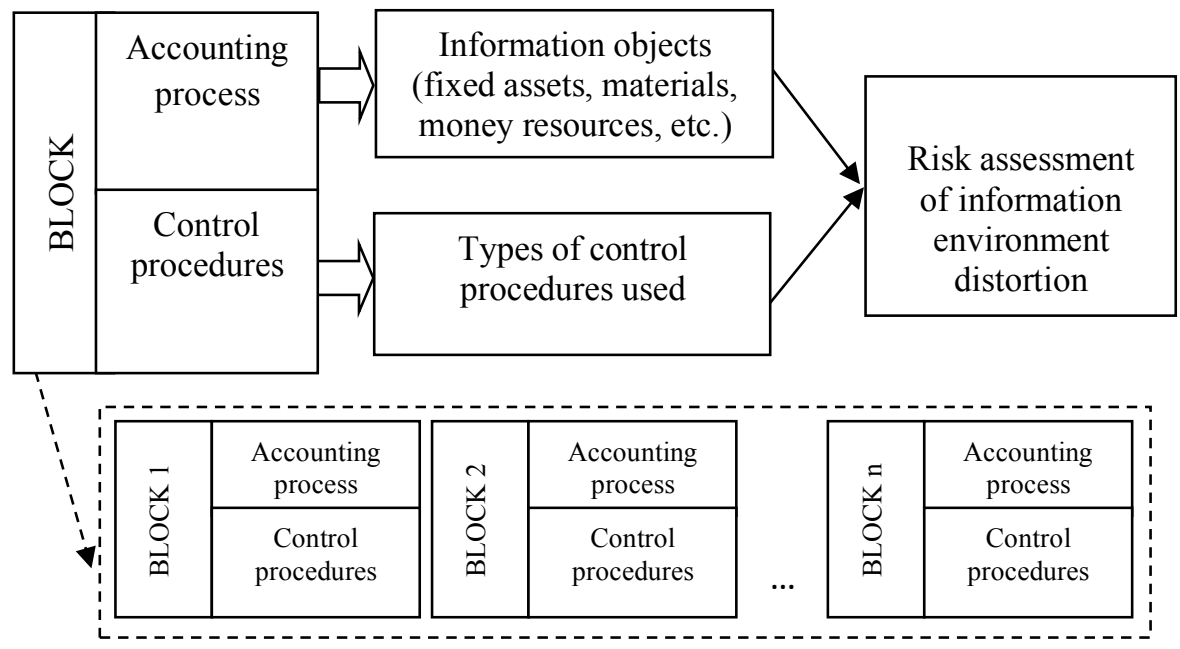

Fig. 1 The proposed structure of accounting and control procedures blocks

The sequence of blocks formation using the blockchain technology can be based on the stages of accounting information formation, which is represented by the following sequence:

1. Local regulation of accounting and control procedures of an economic entity.

2. Confirmation of economic events by accounting source documents.

3. Registration of accounting source documents in accordance with the applicable form of accounting information processing.

4. Coding of economic events (accounting records) in synthetic and analytical accounting.

5. Summary of economic events in the registers of accounting and accounting financial statements [9].

As we said earlier, it is impossible to consider accounting and control beyond a single system.

Internal control refers to a procedure aimed at achieving maximum reliability and reduces to the following facts: an economic entity ensures rational activity, achieves certain financial and operational indicators, provides accounting (financial) statements in a timely and complete manner, and also complies with accounting standards established at the legislative level [10].

Control procedures are generally typical, but the sequence of their application, taking into account the specifics of the organization's activities, the form of accounting information processing, and the approved accounting policy, allows us to obtain different audit results. Accordingly, the control procedures applied by an economic entity do not always cover all the risks of accounting information misstatement. Therefore, it is necessary to evaluate the control procedures applied in order to identify risks and minimize them.

Assessing the coverage completeness of possible distortion risk of the information environment by accounting and control procedures can be presented in the form of a certain risks matrix.

The main purpose of the risks matrix of the information environment distortion is to compare the risks that affect the performance of an economic entity. Comparing risks leads to the identification of disadvantages in each block of accounting and control procedures to be followed by their comprehensive assessment. In addition, the availability of such a matrix contributes to the optimal allocation of resources and rational prioritization. In the proposed version of risks matrix of the information environment distortion, four main elements can be distinguished (Figure 2). 


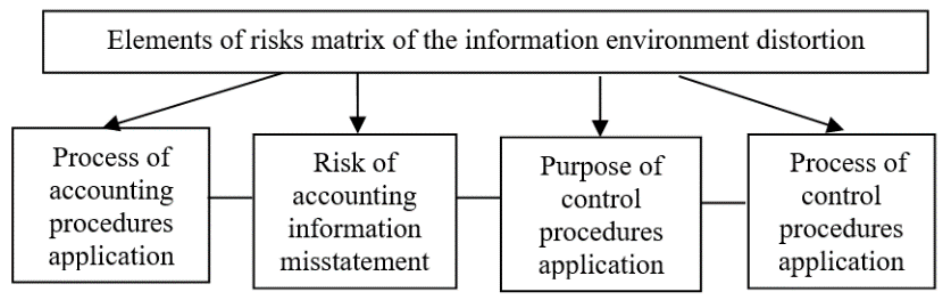

Fig. 2. Elements of risks matrix of the information environment distortion

Based on the probability of possible distortion of accounting and reporting data, we have proposed the following content of accounting and control procedures blocks to be used in the blockchain technology (Figure 3).

\begin{tabular}{|c|c|c|}
\hline \multirow{2}{*}{$\begin{array}{c}\text { BLOCK 1 } \\
\text { Local } \\
\text { regulation of } \\
\text { accounting } \\
\text { and control } \\
\text { procedures of } \\
\text { an economic } \\
\text { entity }\end{array}$} & \multirow{2}{*}{$\begin{array}{c}\begin{array}{c}\text { Accounting } \\
\text { procedures }\end{array} \\
\begin{array}{c}\text { Control } \\
\text { procedures }\end{array}\end{array}$} & $\begin{array}{l}\text { Development and approval of local normative acts for the } \\
\text { regulation of organizational and methodological aspects of } \\
\text { accounting and control procedures application }\end{array}$ \\
\hline & & $\begin{array}{l}\text { 1. Verification of compliance of accounting policy structure } \\
\text { with the current legal and regulatory framework. } \\
2 \text {. Compliance with the adopted accounting policy by an } \\
\text { economic entity. } \\
\text { 3. Review of accounting policy content in accordance with the } \\
\text { current legislative and regulatory framework. }\end{array}$ \\
\hline- & & \\
\hline BLOCK 2 & $\begin{array}{l}\text { Accounting } \\
\text { procedures }\end{array}$ & $\begin{array}{l}\text { Preparation of accounting source documents in connection with } \\
\text { the performed economic events }\end{array}$ \\
\hline $\begin{array}{l}\text { Confirmation } \\
\text { of economic } \\
\text { events by } \\
\text { accounting } \\
\text { source } \\
\text { documents }\end{array}$ & $\begin{array}{l}\text { Control } \\
\text { procedures }\end{array}$ & $\begin{array}{l}\text { 1. Verification of applicable accounting documents for } \\
\text { compliance with the requirements of legal and regulatory } \\
\text { framework. } \\
\text { 2. Checking the completeness of filling in the particulars of } \\
\text { accounting source documents. } \\
\text { 3. Verification of information reliability in accounting source } \\
\text { documents. }\end{array}$ \\
\hline BLOCK 3 & $\begin{array}{l}\text { Accounting } \\
\text { procedures }\end{array}$ & $\begin{array}{l}\text { Assigning numeration to accounting source documents } \\
\text { concerning the performed economic events }\end{array}$ \\
\hline $\begin{array}{l}\text { Registration of } \\
\text { accounting source } \\
\text { documents in } \\
\text { accordance with } \\
\text { the applicable } \\
\text { form of } \\
\text { accounting } \\
\text { information } \\
\text { processing }\end{array}$ & $\begin{array}{c}\text { Control } \\
\text { procedures }\end{array}$ & $\begin{array}{l}\text { 1. Checking the consecutive numbering of accounting source } \\
\text { documents } \\
\text { 2. Comparison of recording dates and registration of accounting } \\
\text { source documents } \\
\text { 3. Authorization of access to the automated system of } \\
\text { registration of accounting source documents. }\end{array}$ \\
\hline BLOCK 4 & $\begin{array}{l}\text { Accounting } \\
\text { procedures }\end{array}$ & $\begin{array}{l}\text { Recording economic events using accounts in synthetic and } \\
\text { analytical accounting }\end{array}$ \\
\hline $\begin{array}{l}\text { Coding of } \\
\text { economic } \\
\text { events } \\
\text { (accounting } \\
\text { records) in } \\
\text { synthetic and } \\
\text { analytical } \\
\text { accounting }\end{array}$ & $\begin{array}{l}\text { Control } \\
\text { procedures }\end{array}$ & $\begin{array}{l}\text { 1. Verification of accounting records in synthetic accounting in } \\
\text { accordance with the processed information in analytical } \\
\text { accounting. } \\
\text { 2. Verification of accounting records in analytical accounting in } \\
\text { accordance with the requirements of legislative acts of federal } \\
\text { and local regulation. } \\
\text { 3. Assessment of accounting information analyticity related to } \\
\text { economic events. }\end{array}$ \\
\hline BLOCK 5 & $\begin{array}{l}\text { Accounting } \\
\text { procedures }\end{array}$ & $\begin{array}{l}\text { Systematization of analytical and synthetic accounting of } \\
\text { economic events in accounting registers and forms of accounting } \\
\text { financial statements }\end{array}$ \\
\hline $\begin{array}{l}\text { economic } \\
\text { events in the } \\
\text { registers of } \\
\text { accounting } \\
\text { and } \\
\text { accounting } \\
\text { financial } \\
\text { statements }\end{array}$ & $\begin{array}{l}\text { Control } \\
\text { procedures }\end{array}$ & $\begin{array}{l}\text { 1. Comparison of information in analytical and synthetic } \\
\text { accounting registers } \\
2 \text {. Verification of the correct recording of balances in accounting } \\
\text { registers } \\
\text { 3. Checking the performance data correctness of accounting } \\
\text { financial statements (compliance with the principle of "net } \\
\text { balance", etc.) }\end{array}$ \\
\hline
\end{tabular}

Fig. 3. Blocks of accounting and control procedures in the blockchain technology to assess the information environment distortion risk 
Thus, the internal control procedures of an economic entity do not always reduce the information environment distortion risk. Therefore, assessing the risk of the information environment distortion covered by the accounting and control procedures of an economic entity can be the final chain of blocks in the blockchain technology. The whole point of the blocks chain of accounting and control procedures using the blockchain technology is that each of them stores information about the previous one, which allows us to analyze and compare information throughout the entire period of economic entities' activities [11].

Many scientists and practitioners suggest using at least three of the following gradations when evaluating internal control: a) high; b) medium; c) low. This methodology is used to assess the information environment distortion risk, taking into account professional judgments (Figure 4).
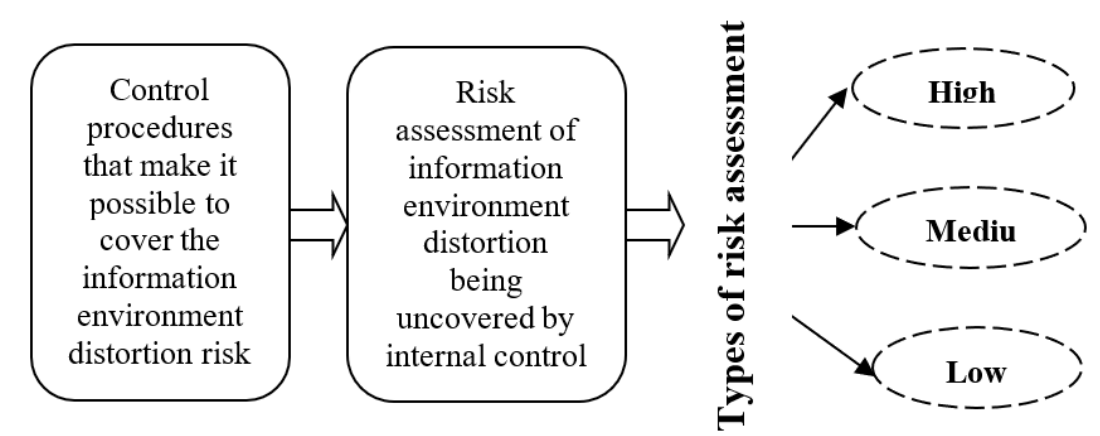

Fig. 4. Sequence of risk assessment of information environment distortion.

The results of the proposed methodology are summarized in Table 1. The selected blocks are based on the sequence of accounting procedures application. To improve the quality of accounting information in the internal control system of an economic entity, control procedures have been developed and systematized. Each proposed procedure is evaluated according to the proposed gradation to assess the information environment distortion risk.

The proposed methodology to assess the information environment distortion risk using the blockchain information technology makes it possible to systematically generate accounting information and manage control procedures to improve the quality of accounting information in order to make effective management decisions.

Thus, depending on the extent to which the information environment risk is covered by internal control procedures, an economic entity will be able to change, supplement the internal control procedures, the accounting process methodology, which will improve the quality of accounting and control procedures as a whole [12].

For external forms of control, this approach is also of practical importance, since at the stage of audit planning, it allows us to evaluate the effectiveness of accounting and control procedures application through a sequential chain in the blockchain information technology, which will lead to a reduction in labor costs and improve the quality of all verification stages. 
Table 1. Methodology for assessing the information environment distortion risk covered by internal control procedures

\begin{tabular}{|c|c|c|}
\hline Block & Control procedures & $\begin{array}{l}\text { Assessment of } \\
\text { coverage of } \\
\text { information } \\
\text { environment } \\
\text { distortion risk } \\
\end{array}$ \\
\hline \multirow{3}{*}{$\begin{array}{l}\text { Local regulation } \\
\text { of accounting and } \\
\text { control } \\
\text { procedures of an } \\
\text { economic entity. }\end{array}$} & $\begin{array}{l}\text { 1. Verification of accounting policy structure } \\
\text { compliance with the current legal and regulatory } \\
\text { framework. }\end{array}$ & High \\
\hline & $\begin{array}{l}\text { 2. Compliance with the adopted accounting policy by an } \\
\text { economic entity. }\end{array}$ & Medium \\
\hline & $\begin{array}{l}\text { 3. Review of accounting policy content in accordance } \\
\text { with the current legislative and regulatory framework. }\end{array}$ & Low \\
\hline \multirow{3}{*}{$\begin{array}{l}\text { Confirmation of } \\
\text { economic events } \\
\text { through } \\
\text { accounting source } \\
\text { documents }\end{array}$} & $\begin{array}{l}\text { 1. Verification of the accounting documents used for } \\
\text { compliance with the requirements of the legal and } \\
\text { regulatory framework. }\end{array}$ & High \\
\hline & $\begin{array}{l}\text { 2. Checking the completeness of filling in the particulars } \\
\text { of accounting source documents }\end{array}$ & Medium \\
\hline & $\begin{array}{l}\text { 3. Verification of information reliability in accounting } \\
\text { source documents }\end{array}$ & Low \\
\hline \multirow{3}{*}{$\begin{array}{l}\text { Registration of } \\
\text { accounting source } \\
\text { documents in } \\
\text { accordance with } \\
\text { the applicable } \\
\text { form of } \\
\text { accounting } \\
\text { information } \\
\text { processing }\end{array}$} & $\begin{array}{l}\text { 1. Checking the consecutive numbering of accounting } \\
\text { source documents }\end{array}$ & High \\
\hline & $\begin{array}{l}\text { 2. Comparison of recording dates and registration of } \\
\text { accounting source documents }\end{array}$ & Medium \\
\hline & $\begin{array}{l}\text { 3. Authorization of access to the automated system of } \\
\text { accounting source documents registration }\end{array}$ & Low \\
\hline \multirow{3}{*}{$\begin{array}{lr}\text { Coding } & \text { of } \\
\text { economic } & \text { events } \\
\text { (accounting } & \\
\text { records) } & \text { in } \\
\text { synthetic } & \text { and } \\
\text { analytical } & \\
\text { accounting } & \end{array}$} & $\begin{array}{l}\text { 1. Verification of accounting records in synthetic } \\
\text { accounting in accordance with the processed } \\
\text { information in analytical accounting }\end{array}$ & High \\
\hline & $\begin{array}{l}\text { 2. Verification of accounting records in analytical } \\
\text { accounting in accordance with the requirements of } \\
\text { legislative acts of federal and local regulation }\end{array}$ & Medium \\
\hline & $\begin{array}{l}\text { 3. Assessment of accounting information analyticity in } \\
\text { relation to the processed economic events }\end{array}$ & Low \\
\hline \multirow{3}{*}{$\begin{array}{lr}\text { Summary } & \text { of } \\
\text { economic } & \text { events } \\
\text { in accounting } \\
\text { registers and } \\
\text { accounting } \\
\text { financial } \\
\text { statements } \\
\end{array}$} & $\begin{array}{l}\text { 1. Comparison of information in analytical and synthetic } \\
\text { accounting registers }\end{array}$ & High \\
\hline & $\begin{array}{l}\text { 2. Verification of the correct recording of balances in } \\
\text { accounting registers }\end{array}$ & Medium \\
\hline & $\begin{array}{l}\text { 3. Checking the performance data correctness of } \\
\text { accounting financial statements (compliance with the } \\
\text { principle of "net balance", etc.) }\end{array}$ & Low \\
\hline
\end{tabular}

\section{References}

1. Alekseeva V. V., Milgunova I. V. Method for assessment of accounting control procedures of economic life facts of economic entities in the audit, Proceedings of Southwest State University. Series: Economics. Sociology. Management. - 2016. - No. 2 (19), Pp. 135-142. 
2. Audit, under the editorship of V. I. Podolskii, 4th ed., rev. and add, M.: UNITI-DANA, 2014, 607 p.

3. Business audit. Practice and development problems: monograph / R.P. Bulyga, M.V. Melnik; Edit. R.P. Bulyga, M.: UNITI-DANA, 2013. - 263 p.

4. Audit: Textbook, A.D. Sheremet, V.P. Suyts. - 6 Ed. - M.: NITS INFRA-M, 2014. $352 \mathrm{p}$.

5. Adams R. Basics of audit / In Y.V. Sokolova [Ed.]; [Trans. from English Y. A. Arienko]. - M.: Audit, 1995.

6. Ahrens E.L., Lobbek J.K. Audit / In Y.V. Sokolova [Ed.]. - M.: Finance and Statistics, 1995.

7. Robertson D. K. Audit, M.: KPMG: Contact, 1993. - 496 p.

8. Decree of the President of the Russian Federation No. 203 of May 9, 2017 "On the Strategy for the Development of the Information Society in the Russian Federation for 2017-2030"

9. Alekseeva V. V., Milgunova I. V. Method for assessment of control procedures in the accounting system, Proceedings of Southwest State University. Series: Economics. Sociology. Management, 2016, No. 4 (21), Pp. 127-135.

10. Alekseeva V.V., Milgunova I.V. The relationship between the assessment of accounting and control procedures and the risks of significant distortion of reporting indicators in the audit [Text] // International multidisciplinary scientific conference on social sciences and arts SGEM 2017, 2017, Volume III, Albena Co, Bulgaria, Pp. 671-678.

11. Alekseeva V.V., Kovalyova A.A. Methodology for assessing the effectiveness of internal control design in the accounting system, Proceedings of Southwest State University. Series: Economics. Sociology. Management, 2017. Volume 7, No. 4 (25), Pp. 203-210.

12. Internal control and analytical support for process management [Text]: monograph / E. A. Bessonova, V. V. Alekseeva, N.A. Gracheva and others; under the General editorship of Dr. Econ. Sciences, Professor E. A. Bessonova. - Kursk-Orel: APLITE, 2012. $220 \mathrm{p}$. 